\title{
Diversity of scale insects (Hemiptera, Coccomorpha) in ten varieties of olive trees (Olea europaea $\mathrm{L}$.) in Southern Brazil
}

\author{
VERA R.S. WOLFF ${ }^{1}$, CAIO F.S. EFROM ${ }^{2}$, DANIELE C. DA SILVA ${ }^{1}$ and ADILSON TONIETTO ${ }^{2}$ \\ ${ }^{1}$ Centro de Pesquisa de Produção Vegetal, DDPA/SEAPI, Rua Gonçalves Dias, 570, 90130-060 Porto Alegre, RS, Brazil \\ ${ }^{2}$ Centro de Pesquisa Emilio Schenk, DDPA/SEAPI, $1^{\circ}$ Distrito, Fonte Grande, 95860-000 Taquari, RS, Brazil
}

Manuscript received on January 4, 2018; accepted for publication on May 21, 2018

\begin{abstract}
Olive production (Olea europaea L.) is a recent activity in Brazil and studies on the adaptability of olive trees varieties in the States are required. One of the problems that can hamper the development of olive trees is the incidence of pests, such as scale insects (Hemiptera, Coccomorpha). In this study, the associated scale insect species were found in ten varieties in an olive grove located at the Research Center of the Serra do Sudeste Region (30 33'15'S, 52²3'45”W) in Brazil. The surveys were carried out twice in each season (2013-2014). Six species of armored scale insect (Diaspididae) and two soft scales (Coccidae) were determined. Saissetia oleae (Coccidae) with $88.15 \%$ and Aspidiotus nerii (Diaspididae) with 5.85\% occurred in all varieties of olive trees. The varieties Arbequina, Frantoio and Cipressino were with greater richness of scale insects, the highest values of diversity occurred in Frantoio, Arbequina and Picual; in Alfafara, Arbosana and Coratina there was a high dominance of one species (S. oleae).
\end{abstract}

Key words: adaptability, Coccidae, Diaspididae, pest insects, olive varieties.

\section{INTRODUCTION}

Commercial crops of olive trees (Olea europaea L., Oleaceae) are being developed in the State of Rio Grande do Sul, Southern Brazil.

One recent problem with olive production in this region is the presence of scale insects (Hemiptera, Coccomorpha) (Coutinho et al. 2009, Wolff 2014, Ricalde et al. 2015).

Scale insects suck the sap of host plants and can negatively affect olive trees and reduce the yields of olive fruit and oil (Coutinho 2011, SantaCecília et al. 2014).

Correspondence to: Vera Regina dos Santos Wolff

E-mails: wolff@seapi.rs.gov.br

wolffvera@gmail.com
There are 19 species of scale insects on $O$. europaea, in Brazil (Claps et al. 1999, 2001, Prado et al. 2012, Wolff 2014, Ricalde et al. 2015, GarcíaMorales et al. 2016).

This study surveyed the scale insects species associated in ten olive varieties.

\section{MATERIALS AND METHODS}

The study was conducted in the municipality of Encruzilhada do Sul, in the Research Center of the Serra do Sudeste Region (30³3'15" S, 52 23'45" W), Department of Diagnosis and Agricultural Research - DDPA/SEAPI, Brazil.

The varieties of olive trees (Olea europaea L., Oleaceae) studied were: Alfafara (AL), Arbequina 
(AR), Arbosana (AB), Cipressino (CI), Coratina (CA), Frantoio (FR), Koroneike (KO), Leccino (LE), Manzanilla (MA) and Picual (PI).

The surveys were carried out twice in each season (spring, summer, fall and winter), from April 2013 to February 2014.

For each sample, two branches (upper and lower canopy), each with 20-30 cm long and with at least 20 leaves infested with scale insects, from each of three randomly selected trees, were examined for the presence and number of scale insects.

Scale insects were separated from the substrate, under a stereomicroscope, and quantified by living individuals, with parasite or with perforations in the body after the emergence of the parasitoid.

Microslides were mounted with adult females of scale insects according to the modified technique (Wolff et al. 2014). The scale insects were identified on an optical microscope and incorporated to the Coccoidea collection of Entomological Museum Ramiro Gomes Costa (MRGC) of Plant Production Research Center, Department of Diagnosis and Agricultural Research - DDPA/SEAPI, Porto Alegre, Brasil (Wolff 2014).

The percentage of parasitism associated to scale insects was evaluated without identifying species of parasitoids and without distinguishing between immature and adult stages of scale insects.

The diversity of scales was evaluated by the Shannon-Wiener index (H') and the diversity (or complementary) Simpson (1-D) (Krebs 1998). PAST program (Hammer et al. 2001) was used for these calculations.

\section{RESULTS AND DISCUSSION}

The scale insects Saissetia coffeae (Walker) and Saissetia oleae (Olivier) (Coccidae); Acutaspis paulista (Hempel), Aonidiella aurantii (Maskell), Aspidiotus nerii Bouché, Hemiberlesia cyanophylli (Signoret), Hemiberlesia lataniae (Signoret), and Pinnaspis strachani (Cooley) (Diaspididae) were determined.

The most common scale insect was $S$. oleae $(88.15 \%)$, occurred throughout the year, found in all varieties of olive trees and the highest percentage was in Alfafara (98.25\%); the second scale insect was $A$. nerii (5.85\%), which also occurred in all the varieties; S. coffeae (4.51\%) occurred only in five varieties, the highest percentage was in Arbequina (13.42\%); while the other scale insects occurred in a small percentage $(<1 \%)$ in the olive grove (Table I).

\section{TABLE I}

Number of individuals $(\mathrm{N})$ and relative frequency $(\%)$ (fr) of scale insect species found in ten varieties of olive trees $($ Olea europaea L.) Encruzilhada do Sul, RS, from April 2013 to February 2014. (AL - Alfafara; AR - Arbequina; AB - Arbosana; CI - Cipressino; CA - Coratina; FR - Frantoio; KO - Koroneike; LE - Leccino; MA - Manzanilla; PI - Picual).

\begin{tabular}{|c|c|c|c|c|c|c|c|c|c|c|c|c|c|c|c|c|}
\hline Species & S. $o$ & leae & S. $c$ & offeae & A. & nerii & $A \cdot p c$ & ulista & & antii & & f. & & niae & stra & hani \\
\hline Varieties & $\mathbf{N}$ & fr & $\mathbf{N}$ & fr & $\mathbf{N}$ & fr & $\mathbf{N}$ & fr & $\mathbf{N}$ & fr & $\mathbf{N}$ & fr & $\mathbf{N}$ & fr & $\mathbf{N}$ & fr \\
\hline $\mathrm{AL}$ & 2529 & 98.25 & 0 & 0 & 16 & 0.62 & 27 & 1.05 & 0 & 0 & 2 & 0.08 & 0 & 0 & 0 & 0 \\
\hline AR & 1691 & 75.63 & 300 & 13.42 & 217 & 9.70 & 23 & 1.03 & 4 & 0.18 & 0 & 0 & 0 & 0 & 1 & 0.04 \\
\hline $\mathrm{AB}$ & 513 & 96.61 & 0 & 0 & 17 & 3.20 & 1 & 0.19 & 0 & 0 & 0 & 0 & 0 & 0 & 0 & 0 \\
\hline CI & 862 & 89.05 & 15 & 1.55 & 17 & 1.76 & 41 & 4.24 & 2 & 0.21 & 31 & 3.20 & 0 & 0 & 0 & 0 \\
\hline $\mathrm{CA}$ & 348 & 95.87 & 0 & 0 & 12 & 3.31 & 0 & 0 & 3 & 0.83 & 0 & 0 & 0 & 0 & 0 & 0 \\
\hline FR & 230 & 64.79 & 82 & 23.10 & 36 & 10.14 & 2 & 0.56 & 4 & 1.13 & 1 & 0.28 & 0 & 0 & 0 & 0 \\
\hline $\mathrm{KO}$ & 1532 & 93.41 & 0 & 0 & 98 & 5.98 & 1 & 0.06 & 7 & 0.43 & 0 & 0 & 2 & 0.12 & 0 & 0 \\
\hline LE & 989 & 86.91 & 27 & 2.37 & 102 & 8.96 & 20 & 1.76 & 0 & 0 & 0 & 0 & 0 & 0 & 0 & 0 \\
\hline MA & 868 & 89.95 & 0 & 0 & 92 & 9.53 & 0 & 0 & 2 & 0.21 & 0 & 0 & 2 & 0.21 & 1 & 0.10 \\
\hline PI & 2398 & 85.73 & 188 & 6.72 & 187 & 6.69 & 0 & 0 & 0 & 0 & 6 & 0.21 & 0 & 0 & 18 & 0.64 \\
\hline Total & 11960 & 88.15 & 612 & 4.51 & 794 & 5.85 & 115 & 0.84 & 22 & 0.30 & 40 & 0.37 & 4 & 0.02 & 20 & 0.14 \\
\hline
\end{tabular}


These species occurs in all the major regions of olive cultivation in the world (García-Morales et al. 2016).

Population surveys of scale insects conducted in "Arbequina" in the municipality of Maria da Fé, Southern Minas Gerais/BR, indicated a greater population of $S$. oleae in the summer (Prado et al. 2012).

The population dynamics of $S$. oleae and its parasitism was evaluated in "Arbequina", in olival situated in the municipality of Caçapava do Sul (30³0'43" S, 5329'27" W), Rio Grande do Sul/ BR, collected from April 2012 to March 2013. The greater abundance was in the spring and summer, the temperature was the factor that interfered in this dynamic and the parasitism rate was $3.40 \%$ (Souza et al. 2015).

Aspidiotus nerii occurred throughout the year, in all varieties studied, and the highest percentage was in Frantoio (10.14\%) (Table I).
This species is cosmopolitan and highly polyphagous, found in a variety of host plants, and in olive it is present in several European countries where cultivation is traditional and in Latin America in Argentina, Brazil and Chile (Claps et al. 2001; García-Morales et al. 2016).

The armored scale insects $A$. aurantii, $H$. cyanophylli, H. lataniae and P. strachani (Diaspididae) occurred in a small percentage in the olive grove (Table I). There species, according Wolff (2014), were new records on olive tree in Brazil.

The varieties Arbequina, Frantoio and Cipressino were with greater richness of scale insects; the highest values of diversity occurred in Frantoio, Arbequina and Picual; in Alfafara, Arbosana and Coratina there was a high dominance of one species (S. oleae) (Table II).

Parasitoids were found in five scale insect species, but the percentage of parasitism was higher

TABLE II

Number of scales (N), richness (S), Shannon-Wiener index (H') and diversity Simpson (1-D) in ten varieties of olive trees (Olea europaea L.), 2013-2014, Encruzilhada do Sul, RS. (AL - Alfafara; AR - Arbequina; AB - Arbosana; CI Cipressino; CA - Coratina; FR - Frantoio; KO - Koroneike; LE - Leccino; MA - Manzanilla; PI - Picual).

\begin{tabular}{ccccccccccc}
\hline $\begin{array}{c}\text { Species/ } \\
\text { Index }\end{array}$ & AL & AR & AB & CI & CA & FR & KO & LE & MA & PI \\
\hline $\mathrm{N}$ & 2574 & 2236 & 531 & 968 & 363 & 355 & 1640 & 1138 & 965 & 2797 \\
$\mathrm{~S}$ & 4 & 6 & 3 & 6 & 3 & 6 & 5 & 4 & 5 & 5 \\
$\mathrm{H}$, & 0.1023 & 0.769 & 0.1553 & 0.4957 & 0.1928 & 0.948 & 0.268 & 0.4979 & 0.3521 & 0.5399 \\
1-D & 0.03451 & 0.4005 & 0.06562 & 0.2036 & 0.07978 & 0.5164 & 0.1238 & 0.2358 & 0.1818 & 0.2559 \\
\hline
\end{tabular}

TABLE III

Number of total individuals (N), number of individuals with parasitoid (P), percentage of parasitism of scale insect species found in the area of olive trees (Olea europaea L.) Encruzilhada do Sul, RS, from April 2013 to February 2014.

\begin{tabular}{lccc}
\hline \multicolumn{1}{c}{ Species } & N & P & Parasitism (\%) \\
\hline Saissetia oleae & 11960 & 74 & 0.62 \\
Saissetia coffee & 612 & 2 & 0.32 \\
Aspidiotus nerii & 794 & 253 & 31.86 \\
Acutaspis paulista & 115 & 31 & 26.95 \\
Aonidiella aurantii & 22 & 0 & 0.00 \\
Hemiberlesia cyanophylli & 40 & 0 & 0.00 \\
Hemiberlesia lataniae & 4 & 0 & 0.00 \\
Pinnaspis strachani & 20 & 1 & 5.00 \\
\hline
\end{tabular}


than $1 \%$ only on $A$. nerii $(31.86 \%)$, A paulista (26.95\%) and P. strachani (5\%) (Table III).

\section{ACKNOWLEDGMENTS}

We thanks to Dr. Elder Joel Coelho Lopes, director of the Research Center of Encruzilhada do Sul DDPA-SEAPI and to Mr. Adair da Silva Ramos for the local technical support to the research, to Mr. Heraldo Gomes for the English corrections, to Conselho Nacional de Desenvolvimento Científico e Tecnológico (CNPq) for the postdoctoral fellowship (PDI) to the first author.

\section{REFERENCES}

CLAPS LE, WOLFF VRS AND GONZÁLEZ RH. 1999. Catálogo de las especies de Diaspididae (Hemiptera: Coccoidea) nativas de Argentina, Brasil y Chile. Insecta Mundi 13(3-4): 239-256.

CLAPS LE, WOLFF VRS AND GONZÁLEZ RH. 2001. Catálogo de las Diaspididae (Hemiptera: Coccoidea) exóticas de la Argentina, Brasil y Chile. Rev Soc Entomol Arg 60(1-4): 9-34.

COUTINHO C. 2011. A cochonilha-negra (Saissetia oleae Olivier). Direção Regional de Agricultura e Pesca do Norte DRAPN, Ficha Técnica 39. Disponível em: http://www. drapn.min-agricultura.pt/drapn/conteudos/ft2010/ficha tecnica_39_2011.pdf.

COUTINHO EF, RIBEIRO FC AND CAPPELLARO TH. 2009. Cultivo de Oliveira (Olea europaea L.). Pelotas: Embrapa Clima Temperado, 125 p.
GARCÍA-MORALES M, DENNO BD, MILLER DR, MILLER GL, BEN-DOV Y AND HARDY NB. 2016. ScaleNet: A literature-based model of scale insect biology and systematics. Database. doi: 10.1093/database/ bav118. Available at: http://scalenet.info.

HAMMER O, HARPER DAT AND RYAN PD. 2001. PAST. Paleontological statistics software package for education and data analysis. Palaeontol Electron 4(1): 1-9.

KREBS CJ. 1998. Ecological Methodology, 2nd ed., Addison Wesley: Longman, $620 \mathrm{p}$.

PRADO EC, SANTA-CECÍLIA LVC AND ALVARENGA TM. 2012. Pragas da oliveira, Bioecologia, inimigos naturais e manejo. In: Oliveira no Brasil tecnologias de produção. 772 p. 2012. Empresa de Pesquisa Agropecuária de Minas Gerais, p. 498-515.

RICALDE MP, NAVA DE, LOECK AE, COUTINHO EF, BISOGNIN A AND GARCIA FRM. 2015. Insects related to olive culture in Rio Grande do Sul State, Brazil. Cienc Rural 45(12): 2125-2130.

SANTA-CECÍLIA LVC, PRADO EC AND PEREIRA AB. 2014. Cochonilha-preta da oliveira, bioecologia e controle. Circular Técnica Epamig (194): 1-3.

SOUZA GC, REDAELLI LR AND WOLFF VRS. 2015. Dinâmica populacional de Saissetia oleae (Hemiptera: Coccidae) em oliveira. Rev Bras Frutic 37(4): 852-858.

WOLFF VRS. 2014. Diaspididae (Hemiptera: Coccoidea) en olivo, Olea europaea Linnaeus (Oleaceae), en Brasil. Insecta Mundi 0385: 1-6.

WOLFF VRS, BOTTON M AND SILVA DC. 2014. Diaspidídeos e parasitoides associados ao cultivo da videira no Rio Grande do Sul, Brasil. Rev Bras Frutic 36: 835-840. 